\title{
Parkinsons sykdom og parkinsonisme
}

\author{
Parkinson, parkinson, Parkinsons, Parkinsons sykdom eller parkinsonisme?
}

Nylig ble skrivemåten for Alzheimers sykdom diskutert i Språkspalten (1). Vi vil omtale et annet nevrodegenerativt eponym, nemlig Parkinsons sykdom, som også skrives på mange ulike måter.

\section{Syndrom og diagnose}

Parkinsonisme (med liten p) er en bevegelsesforstyrrelse som skyldes svikt i basalgangliene, og er et klinisk syndrom hvor minst to av fire kardinaltegn er til stede: hviletremor, rigiditet, bradykinesi og posturale endringer (2). Parkinsons sykdom (med stor p) er en nevrodegenerativ sykdom, og er den vanligste årsaken til parkinsonisme. Andre årsaker kan være progredierende supranukleær parese, multippel systematrofi, demens med Lewy-legemer, medikamentutløst parkinsonisme og vaskulær parkinsonisme (3). Selv om Tidsskriftet generelt ikke anbefaler den latinske varianten av sykdomseponymer, bruker fortsatt enkelte begrepet morbus Parkinson.

I engelskspråklig litteratur finner vi både Parkinson's disease og Parkinson disease, noe som kan komplisere databasesøk. Varianten med genitivs-s gir cirka 63000 treff i PubMed, mens uten gir 60 000, der sammenligning av første side med treff viser helt ulike artikler.

\section{James Parkinson}

Parkinsonisme og Parkinsons sykdom har sitt navn etter den britiske legen James Parkinson (1755-1824), som beskrev tilstanden i 1817 som The Shaking Palsy eller paralysis agitans (4). Betegnelsen var noe misvisende, da tilstanden vanligvis ikke medfører pareser. I 1872 ble lidelsen omdøpt til Parkinsons sykdom (maladie de Parkinson) av den franske nevrologen Jean Martin Charcot (1825-93) $(5,6)$.

\section{Helgardering}

I mediene brukes ulike former til å beskrive tilstanden. I VG kan vi lese at «Depresjon øker risiko for Parkinsons» (7). Bergens Tidende melder at «Eivind vil gi Parkinson et yngre ansikt» (8), mens Dagbladet skriver om Michel J. Fox som «... jobber i dag for parkinson-syke» (9). Nettstedet forskning.no velger å helgardere, og bruker i samme artikkel både «Parkinsons», «Parkinson», «Parkinsons sykdom» og «parkinson»(-pasienter) (10). Førstnevnte variant er sannsynligvis inspirert av det engelske Parkinson's. Bokmålsordboka bruker parkinsonisme og Parkinsons sykdom som synonymer, noe som er misvisende (11).

\section{Anbefaling}

Vi anbefaler at man bruker Parkinsons sykdom om den nevrodegenerative sykdommen, og parkinsonisme om det kliniske syndromet.

Kortformer bør helst unngås (1). Vi mener at Parkinson vil være det mest naturlige i sammensatte ord, som i navnet til brukerorganisasjonen Norges Parkinsonforbund. Kortform med genitivs-s, altså Parkinsons, vil klinge fremmed på norsk.

$\mathrm{Vi}$ registrerer at kortformen med stor bokstav ikke samsvarer med anbefalingen fra Språkrådet, som har uttalt at kortformer som regnes som vanlige ord, skrives med små bokstaver, eventuelt med genitivs-s (12). Eksempler som er nevnt er alzheimer(s) og tourette(s) (12). Grensen for når et eponym blir et vanlig ord i norsk allmennspråk, kan diskuteres. I medisinsk terminologi blir det spesielt krevende dersom en slik vag grense fører til at eponymer som ellers er dannet på tilsvarende vis, får en inkonsekvent skrivemåte. Vi tror de fleste norske leger vil føle det mest naturlig å bestille et røntgenbilde av sin Parkinson-pasient.

\section{Kashif Waqar Faiz}

kashif.faiz@medisin.uio.no Lasse Pihlstrøm

Kashif Waqar Faiz (f. 1978) er spesialist i nevrologi, ph.d. og seksjonsleder/overlege og forsker ved henholdsvis Nevroklinikken og Avdeling for helsetjenesteforskning $(H \emptyset K H)$, Akershus universitetssykehus.
Lasse Pihlstrøm (f. 1980) er postdoktor ved Nevrologisk avdeling, Oslo universitetssykehus og stipendiat ved Institutt for klinisk medisin, Universitetet i Oslo. Han forsker på Parkinsons sykdom og parkinsonisme.

\section{Litteratur}

1. Hem E, Rosness TA. Senil og dement. Tidsskr Nor Legeforen 2015; 135: 1764-5.

2. Larsen JP, Beiske AG, Bekkelund SI et al. Motoriske symptomer ved Parkinsons sykdom. Tidsskr Nor Legeforen 2008; 128: 2068-71.

3. Tysnes OB, Vilming ST. Atypisk parkinsonisme. Tidsskr Nor Legeforen 2008; 128: 2077-80.

4. Parkinson J. An Essay on the Shaking Palsy. London: Whittingham and Rowland, 1817.

5. Charcot JM. Cinquième Leçon. De la paralysie agitante. Oeuvres completes, Recueillies et publiées par Bourneville, Paris: Bureaux du Progrès Médical. 1872: 155-89.

6. Goetz CG. The history of Parkinson's disease: early clinical descriptions and neurological therapies. Cold Spring Harb Perspect Med 2011; 1: a008862.

7. Korneliussen I. Depresjon øker risiko for Parkinsons. VG 28.5.2015. www.vg.no/forbruker/helse/ helse-og-medisin/depresjon-oeker-risiko-forparkinsons/a/23459413/(19.8.2016).

8. Pedersen K. Eivind vil gi Parkinson et yngre ansikt. Bergens Tidende 13.6.2015. www.bt.no/nyheter/ lokalt/Eivind-vil-gi-Parkinson-et-yngre-ansikt3379656.html?xtor=RSS-2 (19.8.2016).

9. Graatrud G. «Tilbake til fremtiden»-legenden jobber i dag for parkinson-syke. Dagbladet 21.10.2015. www.dagbladet.no/2015/10/21/kultur/ michael j fox/tilbake til fremtiden/film/ parkinson/41586062/ [19.8.2016)

10. Petersen IB. Parkinsons sprer seg raskere enn antatt. forskning.no 3.6.2013. http://forskning.no/ sykdommer/2013/05/parkinsons-sprer-segraskere-enn-antatt (19.8.2016).

11. Parkinsonisme. I: Bokmålsordboka. http://ordbok.uib.no/perl/ordbok.cgi?OPP= parkinsonisme (15.12.2016).

12. Språkleg førstehjelp. Språkrådet. Statsspråk 2016 , nr. 2. www.sprakradet.no/Vi-og-vart/ Publikasjoner/Statssprak/statssprak-22016/ sprakleg-forstehjelp/ (15.12.2016).

Redaktør: Erlend Hem. 